\title{
Substitution effects of enzymatically saccharified Korean rice wine lees powder on skim milk in yogurt fermentation
}

\author{
Man-Jin In $^{1}$ \\ 요구르트 발효에서 효소로 당화시킨 주박 분해물의 탈지분유 대체 효과
}

인 만 진 ${ }^{1}$

Received: 22 July 2019 / Accepted: 6 September 2019 / Published Online: 30 September 2019

(C) The Korean Society for Applied Biological Chemistry 2019

\begin{abstract}
Yogurt was prepared with different substitution ratio $[10,20,30$, and $50 \%(\mathrm{w} / \mathrm{w})]$ of skim milk with enzymatically saccharified Korean rice wine lees powder (eKRWLP) and fermented with commercially available mixed lactic acid bacteria (Bifidobacterium longum, Lactobacillus acidophilus, Streptococcus thermophilus) at $40{ }^{\circ} \mathrm{C}$ for $18 \mathrm{~h}$. Fermentation characteristics were evaluated in terms of acid production ( $\mathrm{pH}$ and titratable acidity) and viable cell counts of lactic acid bacteria. The $\mathrm{pH}$ of yogurts decreased with increasing eKRWLP substitution ratio of skim milk. After $12 \mathrm{~h}$ fermentation, titratable acidities of eKRWLP substitution and control (yogurt made without eKRWLP) were $0.84 \sim 1.04 \%$ and $0.93 \%$, respectively. The titratable acidities of yogurts prepared with 10 and $20 \%$ substitution ratio increased than that of the control yogurt, but titratable acidities of yogurts of 30 and $50 \%$ substitution ratio decreased. After $9 \mathrm{~h}$ fermentation, the number of viable lactic acid bacterial cell were increased to $8.18 \sim 8.24 \log \mathrm{CFU} / \mathrm{g}$ in all yogurts. In sensory evaluation, there were similar preference for eKRWLP yogurts prepared with 10 and $20 \%$ substitution ratio and the control. When eKRWLP substitution and control yogurts fermented for $9 \mathrm{~h}$ were incubated at $4{ }^{\circ} \mathrm{C}$, their pHs and titratable acidities were slightly changed but
\end{abstract}

Man-Jin In $(\triangle)$

E-mail: manjin@chungwoon.ac.kr

${ }^{1}$ Department of Chemical Engineering, Chungwoon University, Incheon 22100, Republic of Korea

This is an Open Access article distributed under the terms of the Creative Commons Attribution Non-Commercial License (http://creativecommons. org/licenses/by-nc/3.0/) which permits unrestricted non-commercial use, distribution, and reproduction in any medium, provided the original work is properly cited. the number of viable lactic acid bacteria were well maintained above $10^{7} \mathrm{CFU} / \mathrm{g}$ for 11 days in yogurts prepared with 10 and $20 \%$ substitution ratio among eKRWLP substitution yogurts. These results suggest that eKRWLP can be used as substituent of skim milk and the optimum substitution ratio is around $10 \sim 20 \%$.

Keywords Fermentation characteristics · Saccharified Korean rice wine lees powder $\cdot$ Substitution of skim milk $\cdot$ Yogurt

\section{서 론}

탈지유 혹은 우유를 주원료로 젖산균을 발효시켜 제조하는 요 구르트는 주원료 성분 이외에 발효과정에서 젖산균의 작용에 의 하여 생성되는 젖산, 비타민, 펩티드, 향미성분과 젖산균 생균 체를 함유하고 있어 주원료보다 독특한 풍미를 가지며, 소화율 과 정장작용과 같은 생리적인 기능성이 강화된 우수한 발효식 품이다[1]. 최근에는 기존 요구르트에 새로운 생리활성을 부가 시킬 목적으로 다양한 기능성 성분을 함유하고 있는 천연의 부 재료 또는 비타민, 무기질, 섬유질, 불포화 지방산 등을 첨가하 여 요구르트를 제조하는 결과가 보고[2-4]되고 있다.

한편, 쌀을 주원료로 약주, 청주 등의 양조 과정에서 알코올 발효 후 발효액에서 술을 거르고 남는 부산물인 주박은 주원료 인 쌀의 약 $20 \%$ 정도까지 얻어지며, 최근에는 막걸리와 같은 전통주의 소비가 증가하고, 전국적으로 지역 전통주 복원을 통 한 상품화가 활발해짐에 따라 양조 부산물인 주박의 발생량도 증가하고 있다. 양조과정에서 알코올 발효에 사용되지 못한 탄 수화물과 단백질이 주성분인 주박은 과거 식량이 부족했던 시 기에는 대체식품으로 이용되기도 하였으며, 양조과정에서 생성 된 유기산, 비타민, 알코올, 효소와 효모 등을 함유하고 있다[5]. 
현실적으로 부산물인 주박은 높은 수분함량으로 저장성이 낮기 때문에 대부분은 폐기되며, 일부가 채소 절임류의 제조와 사료, 비료 등으로 활용되는 실정이다[6]. 그러나 최근에 혈당 조절 [7], 항알러지[8], 효소활성 저해[9], 항염증[10], 면역 활성화[11] 등의 생리활성 성분이 주박에 존재하는 것으로 보고됨에 따라 이에 대한 활용에 관심이 모아지고 있다. 주박의 활용은 식품 제조과정에서 주박을 첨가하여 식품의 품질을 개선하고 주박의 생리활성을 이용하는 연구[12-15]와 주박을 미생물 배양과 발효 식품에 활용하는 연구[16-18]로 구분할 수 있다. 특히, 요구르 트 발효에서 탈지분유에 주박이나 주박 당화물의 첨가는 젖산 균의 생육과 산의 생성을 촉진하였으며 $[19,20]$, 주박은 발효액 에서 유청의 분리를 억제하여 요구르트 커드의 안정성 향상에 효과가 있는 것으로 보고되었다[19].

따라서 본 연구에서는 다양한 생리활성이 보고되어 있는 주 박을 발효식품에 활용하는 연구의 계속으로 요구르트 발효에 대 한 주박의 영향을 조사하였다. 구체적으로, 요구르트의 주원료 인 탈지분유의 일부를 효소로 당화시킨 주박 당화물로 대체하 여 요구르트를 제조하였으며 젖산균의 발효특성과 관능적 특성, 요구르트 발효액의 저장 안정성을 조사함으로써 주박 효소 당 화물이 요구르트 발효에 이용될 수 있는 첨가량에 관한 기초적 인 자료를 확보하고자 본 연구를 수행하였다.

\section{재료 및 방법}

\section{재료}

결성양조장(홍성, 대한민국)에서 생산된 막걸리 발효 원액을 구 입하여 원심분리 $\left(1,000 \times g, 4{ }^{\circ} \mathrm{C}, 15\right.$ 분 $)$ 로 상등액을 제거하고 침 전물을 동결 건조하여 주박 분말을 준비하였으며, 탈지분유는 서울우유협동조합의 제품을 사용하였다. 요구르트 발효의 starter 로는 Bifidobacterium longum, Lactobacillus acidophilus, Streptococcus thermophilus 3종 유산균의 혼합 제품인 ABT-B Yogurt Culture (Danisco USA Inc., Madison, WI, USA)를 별도의 배 양 없이 사용하였다.

\section{주박 효소 당화물의 제조 및 요구르트 배양}

주박 효소 당화물은 기존의 보고[21]에 준하여 동결 건조한 주 박 분말을 $20 \%$ 로 현탁하여 $80{ }^{\circ} \mathrm{C}$ 에서 10 분간 열처리하고 $\alpha$ amylase와 glucoamylase (Sigma Chem., St. Louis, MO, USA) 을 순차적으로 처리하여 주박에 함유된 전분을 분해시킨 후 동 결 건조하여 제조하였다. 주박 효소 당화물을 함유한 요구르트 의 발효는 탈지분유 $10 \%$ 현탁액을 기준으로 탈지분유 사용량 의 $10 \sim 50 \%$ 를 주박 효소 당화물로 대체하여 혼합하고 $100{ }^{\circ} \mathrm{C}$ 에 서 10 분간 열처리한 다음 실온으로 냉각시킨 후 $0.02 \%$ 로 starter를 첨가하여 $40{ }^{\circ} \mathrm{C}$ 에서 정치배양으로 실시하였다.

\section{$\mathrm{pH}$ 와 적정산도}

요구르트 발효액의 $\mathrm{pH}$ 는 $\mathrm{pH}$ meter (model 915DC, Istek, 서 울, 대한민국)를 이용하여 직접 측정하였으며, 적정산도는 시료 를 멸균 식염수로 10 배 희석한 후 phenolphthalein을 지시약으 로 하여 $0.01 \mathrm{~N} \mathrm{NaOH}$ 로 적정하여 젖산 함량으로 나타내었다.

\section{환원당}

요구르트 발효액을 적당히 희석한 후 포도당을 표준물질로 하 여 3,5-dinitrosalicylic acid (DNS)법으로 분석하여 환원당 함량 을 측정하였다.

\section{젓산균 생균수}

요구르트 발효액 $1 \mathrm{~g}$ 을 채취하여 멸균 생리식염수에 단계적으 로 희석하고 젖산균 배양용 배지(Lactobacillus MRS agar, Difco Laboratories, Detroit, MI, USA)에 $1 \mathrm{~mL}$ 씩 pour plate method로 혼합한 다음 $37^{\circ} \mathrm{C}$ 에서 24 36시간 배양하여 형성된 colony를 계측하였다. 젖산균 생균수는 시료 $\mathrm{g}$ 당 colony forming units $(\mathrm{CFU} / \mathrm{g})$ 로 나타내었다.

\section{관능검사와 통계분석}

관능검사는 12 시간 발효시킨 요구르트 발효액에 설탕을 $5 \%$ 첨 가하고 $4{ }^{\circ} \mathrm{C}$ 에서 24 시간 보관한 시료에 대하여 청운대학교 식 품영양학과 학생 20 명에게 맛, 향, 점도, 종합적인 기호도를 5 점 척도법[아주 싫다(1점), 보통이다(3점), 아주 좋다(5점)]으로 실시하였다[22]. 관능검사 결과는 SPSS Statistics (Statistical Package for Social Science, SPSS Inc., Chicago, IL, USA, version 23.0)를 이용하여 일원배치 분산분석(ANOVA)으로 통계 처리 하였으며, 각 시료간의 유의적인 차이는 Duncan's multiple range test로 검증하였다(유의수준 $p<0.05$ ).

\section{저장성}

요구르트 발효액의 저장성은 9 시간 발효시킨 발효액을 $4{ }^{\circ} \mathrm{C}$ 에 서 14 일간 보관하면서 $\mathrm{pH}$, 적정산도, 젖산균수의 변화를 경시 적으로 조사하였다.

\section{결과 및 고찰}

\section{주박 효소 당화물}

요구르트 제조에 이용되는 starter 유산균의 대부분은 전분 분해 효소의 활성이 결여되었거나 미미하므로 우유 이외에 전분을 함 유한 원료를 부원료로 요구르트 제조에 사용하는 경우, 특히 우 유나 탈지분유의 일부를 대체하는 경우 부원료에 함유된 전분 을 유산균이 발효에 이용될 수 있는 저분자로 분해하는 당화가 필요하다[22]. 본 연구에 사용된 막걸리 주박 분말의 총탄수화 물은 $79.40 \%$, 환원당은 $3.20 \%$ 로 탄수화물의 대부분이 유산균 이 이용하기 어려운 비발효성 당류이므로[19], 주박에 $\alpha$-amylase 와 glucoamylase를 순차적으로 처리하여 주박 효소 당화물을 준 비하였다. 주박 효소 당화물의 환원당 함량은 효소처리 전 주 박의 3.20 에서 $73.0 \%$ 로 크게 증가되어[20] 주박에 함유된 비발 효성 당류의 대부분이 저분자 당류로 분해된 것으로 판단된다.

\section{$\mathrm{pH}$ 와 적정산도의 변화}

탈지분유 $10 \%(\mathrm{w} / \mathrm{w})$ 를 기준으로 주박 효소 당화물로 탈지분유 사용량의 0 (대조군), $10,20,30,50 \%$ 를 대체하여 준비한 현탁 액을 $40{ }^{\circ} \mathrm{C}$ 에서 18 시간 동안 발효시키며 $\mathrm{pH}$ 와 적정산도의 변화 를 측정하였다. 발효액의 $\mathrm{pH}$ 변화는 모든 실험군에서 동일한 경 

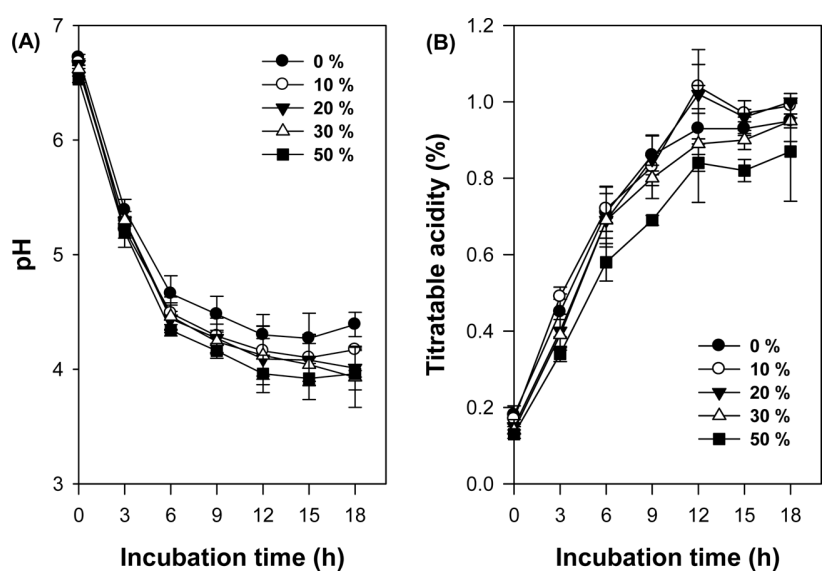

Fig. 1 Change in pH (panel A) and titratable acidity (panel B) of yogurt prepared with different substitution ratios of skim milk with enzymatically saccharified Korean rice wine lees powder during fermentation at $40^{\circ} \mathrm{C}$ for $18 \mathrm{~h}$

향으로 발효 12 시간까지 급격하게 감소한 후 그 이후 발효 18 시간까지 $\mathrm{pH}$ 변화는 미미하였으며, 주박 효소 당화물을 사용한 실험군의 $\mathrm{pH}$ 가 대조군보다 항상 낮은 값을 보였다(Fig. 1A). 발 효 시작점에서의 $\mathrm{pH}$ 는 주박 효소 당화물의 첨가량에 비례하여 다소 낮아졌으며66.72 (대조군), 6.68 (10\% 대체), $6.66(20 \%$ 대체), 6.62 (30\% 대체), 6.53 (50\% 대체)], 이는 쌀 막걸리를 첨가한 요구르트의 결과[23]와 매우 유사하였다. 배양 12시간 후 대조군의 $\mathrm{pH}$ 는 4.30, 주박 효소 당화물 요구르트의 $\mathrm{pH}$ 는 4.16 (10\% 대체), 4.09 (20\% 대체), 4.12 (30\% 대체), 3.96 (50\% 대체)으로 주박 당화물로 탈지분유를 대체한 조건에서 더 낮은 $\mathrm{pH}$ 를 나타냈으며, $\mathrm{pH}$ 감소는 주박 당화물의 사용량에 비례하였 다. 이러한 변화는 주박 효소 당화물을 $0.5 \sim 2.0 \%$ 첨가한 요구 르트[20]와 탈지분유의 $10 \sim 50 \%$ 를 자색 고구마 효소 분해물로 대체한 요구르트[22]에서도 동일한 경향으로 보고되었다. 배양 18 시간 후 모든 실험군에서 $\mathrm{pH}$ 는 3.96 4.39로 국내에서 시판되 는 발효유의 $\mathrm{pH}$ (3.46 4.15)와 농후 발효유의 $\mathrm{pH}$ (4.17 4.56)에 관한 결과[24] 및 요구르트의 $\mathrm{pH}$ 는 3.27 4.53이 적당하다는 보 고[25]에 잘 부합되었다. 발효 중 적정산도는 $\mathrm{pH}$ 와 유사하게 대 조군과 실험군에서 모두 발효 12시간까지 급격하게 증가하였다 (Fig. 1B). 배양 12시간 후 대조군의 적정산도는 $0.93 \%$, 주박 효 소 당화물 요구르트의 적정산도는 1.04 (10\% 대체), $1.02(20 \%$ 대체), 0.86 (30\% 대체), 0.84 (50\% 대체)로 탈지분유의 대체율 이 낮은 조건(10 20\%)에서는 대조군 보다 산의 생성이 증가되 었지만 탈지분유의 $30 \%$ 이상을 주박 당화물로 대체하면 산의 생성이 감소하는 것으로 나타났다. 이러한 경향은 탈지분유에 주박 혹은 주박 효소 당화물을 추가로 첨가하면 산의 생성이 비 례적으로 증가하였다는 결과[19,20]를 고려하면 탈지분유의 대 체율이 낮은 조건(10 20\% 대체)에서는 주박에 함유된 미량의 발효촉진물질이, 대체율이 높은 조건(30 50\% 대체)에서는 탈지 분유의 사용량 감소가 원인인 것으로 판단된다. 또한 쌀 막걸리 를 첨가한 요구르트에서 막걸리 사용량에 비례하여 적정산도가 증가하였다는 보고[23]와 상이한 것은 본 연구는 탈지분유에 추 가로 주박 혹은 주박 분해물을 첨가한 것이 아니라 탈지분유의
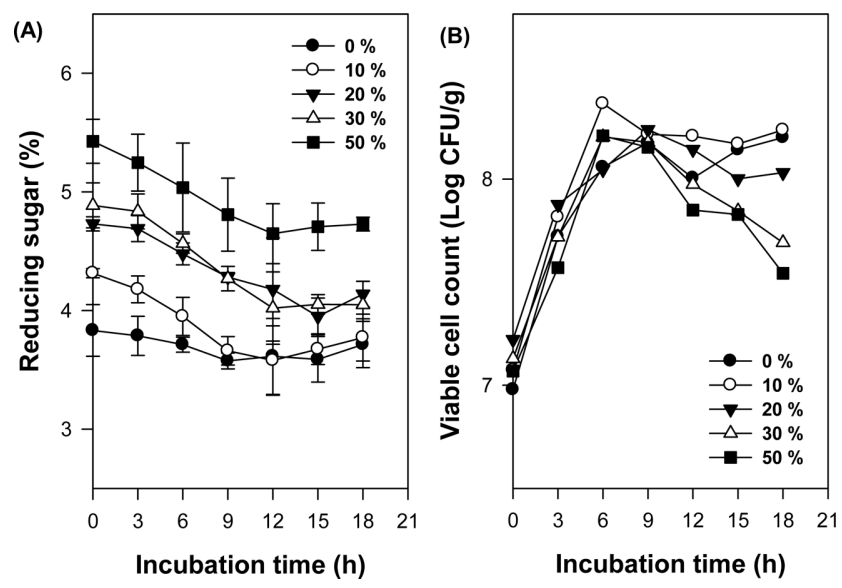

Fig. 2 Change in reducing sugar contents (panel A) and lactic acid bacteria counts (panel B) of yogurt prepared with different substitution ratios of skim milk with enzymatically saccharified Korean rice wine lees powder during fermentation at $40{ }^{\circ} \mathrm{C}$ for $18 \mathrm{~h}$

사용량을 줄이고 주박 분해물로 대체하여 요구르트 발효에 사 용하였기 때문이다. 자색 고구마 효소 분해물로 탈지분유를 대 체하는 경우 대체 정도에 비례하여 산의 생성이 감소한 결과[22] 와 비교하면 자색 고구마 효소 분해물보다 주박 효소 당화물이 산의 생성에 도움이 되는 것으로 나타났다. 배양 18 시간 후 모 든 실험군의 적정산도는 $0.87 \sim 1.0 \%$ 로 국내에서 시판되는 발효 유의 적정산도(0.45 0.94)와 농후 발효유의 적정산도(0.75 1.02) 에 관한 결과[24] 및 한국인에게 기호도가 높은 요구르트의 적 정산도는 $0.85 ~ 1.20 \%$ 라는 보고[26]에 부합하였다.

\section{환원당과 젓산균 수의 변화}

탈지분유의 일부를 주박 효소 당화물로 대체하여 발효한 요구 르트의 환원당 함량의 변화는 Fig. $2 \mathrm{~A}$ 와 같다. 발효 시작점에 서 환원당 함량은 주박 분해물의 높은 환원당 함량 $(73.0 \%)$ 으로 $3.83 \%$ (대조군)에서 4.32 (10\% 대체), 4.73 (20\% 대체), 4.89 (30\% 대체), $5.43(50 \%$ 대체)로 증가하였다. 배양 12 시간 후 환원당 함량은 $3.61 \%$ (대조군), 3.58 (10\% 대체), $4.18(20 \%$ 대체 $), 4.02$ (30\% 대체), 4.65 (50\% 대체)로 감소하였다. 이는 환원당이 젖산균의 생육에 영양원으로 이용되어 유기산, $\mathrm{CO}_{2}$ 등의 물질로 전환된 것을 나타내지만 실험군에는 유당뿐만 아 니라 전분 분해물의 환원당이 공존하므로 $\mathrm{DNS}$ 법으로 측정한 환원당 함량의 변화와 적정산도의 변화(Fig. 1B)가 다소 상이한 것으로 판단되었다. 한편, 주박 당화물의 탈지분유 대체 정도에 따른 젓산균 생균수의 변화는 Fig. $2 \mathrm{~B}$ 와 같다. 발효 시작점에 서 젖산균 수는 대조군과 모든 실험군에서 6.98 7.22 $\log \mathrm{CFU} /$ $\mathrm{g}$ 으로 유사하였으나, 발효 6 9시간까지 급격하게 증가하였다. 발효 9시간 후 젖산균 수는 $8.18 \log \mathrm{CFU} / \mathrm{g}$ (대조군), 8.22 $\log \mathrm{CFU} / \mathrm{g}$ (10\% 대체), $8.24 \log \mathrm{CFU} / \mathrm{g}$ (20\% 대체), 8.18 $\log \mathrm{CFU} / \mathrm{g}$ (30\% 대체), $8.15 \log \mathrm{CFU} / \mathrm{g}$ (50\% 대체)에서 발 효 18 시간에는 $8.20 \log \mathrm{CFU} / \mathrm{g}$ (대조군), $8.24 \log \mathrm{CFU} / \mathrm{g}$ (10\% 대체), $8.03 \log \mathrm{CFU} / \mathrm{g}(20 \%$ 대체), $7.69 \log \mathrm{CFU} / \mathrm{g}$ (30\% 대체), $7.54 \log \mathrm{CFU} / \mathrm{g}$ (50\% 대체)로 조사되어 탈지분유 의 사용량이 $30 \sim 50 \%$ 대체된 요구르트에서 생균수가 감소하였 
Table 1 Sensory evaluation results of yogurt prepared with different substitution ratios of skim milk with enzymatically saccharified Korean rice wine lees powder after fermentation at $40{ }^{\circ} \mathrm{C}$ for $12 \mathrm{~h}$

\begin{tabular}{cccc}
\hline \hline Substitution ratio (\%) & Taste & Flavor & Viscosity \\
\hline 0 & $3.55 \pm 0.89^{\mathrm{a}}$ & $3.45 \pm 0.95$ & $3.65 \pm 0.81$ \\
10 & $3.30 \pm 0.98^{\mathrm{a}}$ & $3.25 \pm 0.91$ & $3.35 \pm 0.75$ \\
20 & $3.00 \pm 0.92^{\mathrm{ab}}$ & $3.25 \pm 0.85$ & $3.65 \pm 0.75$ \\
30 & $2.65 \pm 0.93^{\mathrm{bc}}$ & $3.25 \pm 0.97$ & $3.40 \pm 0.82$ \\
50 & $2.15 \pm 1.04^{\mathrm{c}}$ & $2.85 \pm 0.93$ & $2.95 \pm 1.23$ \\
\hline
\end{tabular}

${ }^{1)}$ Data are means $\pm \mathrm{SD}(\mathrm{n}=20)$

${ }^{2)}$ Different superscripts within column indicate significant difference $(p<0.05)$

Table 2 Changes in quality of yogurt prepared with different substitution ratios of skim milk with enzymatically saccharified Korean rice wine lees powder during storage at $4{ }^{\circ} \mathrm{C}$

\begin{tabular}{|c|c|c|c|c|c|c|c|c|}
\hline & \multirow{2}{*}{$\begin{array}{c}\text { Substitution ratio } \\
(\%)\end{array}$} & \multicolumn{7}{|c|}{ Storage period (day) } \\
\hline & & 0 & 2 & 4 & 7 & 9 & 11 & 14 \\
\hline \multirow{5}{*}{$\mathrm{pH}$} & 0 & 4.40 & 4.34 & 4.42 & 4.35 & 4.41 & 4.45 & 4.50 \\
\hline & 10 & 4.25 & 4.19 & 4.25 & 4.19 & 4.25 & 4.31 & 4.36 \\
\hline & 20 & 4.19 & 4.15 & 4.19 & 4.18 & 4.19 & 4.26 & 4.30 \\
\hline & 30 & 4.15 & 4.13 & 4.17 & 4.10 & 4.14 & 4.22 & 4.28 \\
\hline & 50 & 4.08 & 4.05 & 4.05 & 4.09 & 4.06 & 4.11 & 4.17 \\
\hline \multirow{5}{*}{$\begin{array}{l}\text { Titratable } \\
\text { acidity } \\
(\%)\end{array}$} & 0 & 0.94 & 0.87 & 0.86 & 0.91 & 0.91 & 0.90 & 0.90 \\
\hline & 10 & 1.02 & 0.91 & 0.95 & 0.94 & 0.94 & 0.94 & 0.94 \\
\hline & 20 & 0.98 & 0.89 & 0.92 & 0.89 & 0.91 & 0.92 & 0.94 \\
\hline & 30 & 0.86 & 0.83 & 0.91 & 0.84 & 0.86 & 0.85 & 0.85 \\
\hline & 50 & 0.78 & 0.73 & 0.77 & 0.75 & 0.75 & 0.76 & 0.76 \\
\hline \multirow{5}{*}{$\begin{array}{c}\text { Viable cell } \\
\text { counts } \\
(\mathrm{CFU} / \mathrm{g})\end{array}$} & 0 & $5.60 \times 10^{8}$ & $4.60 \times 10^{8}$ & $5.13 \times 10^{8}$ & $2.11 \times 10^{8}$ & $6.17 \times 10^{7}$ & $1.47 \times 10^{7}$ & $3.70 \times 10^{7}$ \\
\hline & 10 & $7.60 \times 10^{8}$ & $1.69 \times 10^{8}$ & $1.29 \times 10^{8}$ & $3.47 \times 10^{8}$ & $2.72 \times 10^{8}$ & $2.04 \times 10^{8}$ & $4.86 \times 10^{7}$ \\
\hline & 20 & $5.73 \times 10^{8}$ & $2.02 \times 10^{8}$ & $1.29 \times 10^{8}$ & $1.41 \times 10^{8}$ & $7.80 \times 10^{7}$ & $1.83 \times 10^{7}$ & $3.07 \times 10^{6}$ \\
\hline & 30 & $1.43 \times 10^{8}$ & $1.45 \times 10^{8}$ & $1.73 \times 10^{8}$ & $1.28 \times 10^{8}$ & $4.35 \times 10^{7}$ & $6.90 \times 10^{6}$ & $3.27 \times 10^{6}$ \\
\hline & 50 & $1.18 \times 10^{8}$ & $5.57 \times 10^{7}$ & $4.20 \times 10^{7}$ & $2.72 \times 10^{7}$ & $7.30 \times 10^{6}$ & $6.90 \times 10^{6}$ & $4.00 \times 10^{5}$ \\
\hline
\end{tabular}

다. 이러한 생균수의 변화는 적정산도의 변화(Fig. 1B)와 일치 하는 경향이었다. 젖산균은 생육에 아미노산, 비타민, 핵산(퓨린 또는 피리미딘) 등의 복합영양소를 요구하므로 요구르트 발효 에서는 탈지분유에 함유된 복합영양소를 이용하는 바 탈지분유 사용량의 30 50\%를 주박 효소 당화물로 대체한 조건에서는 복 합영양소의 부족으로 발효 후기에 생균수가 감소하는 것으로 사 료된다[22]. 본 연구에서 발효 9시간 후 주박 효소 당화물을 사 용한 모든 실험군의 젖산균 수는 $10^{8} \mathrm{CFU} / \mathrm{g}$ 이상으로 신선한 액상 및 호상 발효유의 젖산균 수는 각각 $10^{7}$ 과 $10^{8} \mathrm{CFU} / \mathrm{mL}$ 이상으로 규정하고 있는 축산물 성분규격에 부합하였다[27]. 따 라서 요구르트 제조시 주박 효소 당화물로 탈지분유를 부분적 으로 대체할 수 있을 것으로 확인되었다. 뿐만 아니라 탈지분 유에 추가한 주박 당화물의 첨가량에 비례하여 젖산균의 생육 이 증가한 보고[20]를 참고하면 주박 효소 당화물은 미생물 배 양에 효과적인 배지성분으로 이용 가능하므로 산업적인 측면에 서 양조 부산물의 고부가가치화에 기여할 수 있을 것이다.

\section{관능특성}

주박 효소 당화물로 탈지분유의 대체 정도를 다르게 하여 $40^{\circ} \mathrm{C}$ 에서 12 시간 발효시킨 요구르트에 설탕 $5 \%$ 를 첨가하고 $4{ }^{\circ} \mathrm{C}$ 에
서 24시간 보관 후 맛, 향, 점도 및 종합적인 기호도에 대한 관 능평가를 실시하였다(Table 1). 관능평가 점수는 모든 항목에서 대조군이 주박 효소 당화물로 탈지분유를 대체한 요구르트보다 다소 높게 나타났으며, 주박 효소 당화물의 사용량에 비례하여 관능적인 평가점수는 감소하였다. 그러나 향과 점도 항목은 대 조군와 모든 실험구간의 통계적으로 유의한 차이는 없었으며, 맛 항목은 대조군와 탈지분유의 10 과 $20 \%$ 대체 요구르트가, 종 합적인 기호도 항목은 대조군와 탈지분유의 $10,20,30 \%$ 대체 요구르트가 통계적으로 차이가 없었다. 이러한 주박 효소 당화 물에 의한 탈지분유의 대체율이 증가할수록 관능특성이 감소하 는 경향은 탈지분유에 주박 효소 당화물을 첨가한 요구르트[20] 와 막걸리를 첨가한 요구르트[23]에서도 동일하게 보고되었다. 자색 고구마 효소 분해물로 본 연구와 동일한 수준으로 탈지분 유를 대체한 요구르트는 모든 평가항목에서 유의차가 없다는 보 고[22]와 상이한 것은 시료의 차이에 의한 것이다. 관능평가 결 과 탈지분유의 $10 \sim 20 \%$ 를 주박 효소 당화물로 대체하는 것이 가능하며, 시판 요구르트에 부재료로 함유된 감미료, 물성개선 제, 유화제, 향료 등이 사용되는 점[27]을 참고하면 상품화 과 정에서 추가되는 부재료에 의하여 관능특성이 향상될 수 있을 것으로 판단된다. 


\section{저장성}

우리나라 발효유는 $0 \sim 10{ }^{\circ} \mathrm{C}$ 에서 냉장 유통되므로 저온에서 저 장 안정성을 확인하기 위하여 탈지분유의 일부를 주박 효소 당 화물로 대체하여 $40{ }^{\circ} \mathrm{C}$ 에서 9 시간 발효시켜 제조한 요구르트를 $4{ }^{\circ} \mathrm{C}$ 에서 냉장 보관하면서 14 일 동안 $\mathrm{pH}$, 적정산도, 젖산균 수 의 변화를 조사하였다(Table 2). 저장 14 일까지 대조군와 모든 실험군의 $\mathrm{pH}$ 와 적정산도의 변화는 미미하였다. 이러한 경향은 유통과정에서 적정산도가 $1.5 \%$ 까지 증가한다는 보고[28]와는 상 이하였으나 탈지분유에 주박 효소 당화물을 첨가한 요구르트의 저장성[20]과는 매우 유사하였다. 그러나 저장기간 동안 젓산균 수는 주박 당화물로 탈지분유를 부분적으로 대체한 실험군에서 주박 효소 당화물의 탈지분유 대체 정도에 비례하여 감소하였 다. 주박 효소 당화물 대체 요구르트의 생균수가 $10^{8} \mathrm{CFU} / \mathrm{g}$ 이 상으로 유지되는 기간이 11 일 ( $10 \%$ 대체), 7 일 ( $20 \%$ 대체), 7 일 $(30 \%$ 대체 $)$ 이었고, $50 \%$ 대체 요구르트에서는 저장 2 일부터 생균수가 $10^{8} \mathrm{CFU} / \mathrm{g}$ 미만으로 감소하였다. 액상 발효유의 젖산 균 수는 $10^{7} \mathrm{CFU} / \mathrm{mL}$ 이상이며 $0 \sim 10^{\circ} \mathrm{C}$ 에서 냉장 보관시 권장 유통기간이 10 일인 점[27]을 고려하면 저장 11 일까지 생균수가 $10^{7} \mathrm{CFU} / \mathrm{g}$ 이상으로 유지되는 탈지분유의 $10 \sim 20 \%$ 를 주박 효 소 당화물로 대체하여 제조한 요구르트가 우수한 저장성을 보 이는 것으로 판단된다.

\section{초 록}

본 연구에서는 주박을 발효식품에 이용하기 위하여 요구르트 제 조의 주원료인 탈지분유를 주박 효소 당화물로 대체 $(10,20,30$, $50 \%$ )한 실험군과 탈지분유만을 사용한 대조군을 상업용 Bifidobacterium longum, Lactobacillus acidophilus, Streptococcus thermophilus 혼합 균주로 요구르트 발효를 실시하면서 발효특 성을 비교하고, 발효 후 요구르트의 관능특성과 저장성을 조사 하였다. 요구르트의 $\mathrm{pH}$ 는 배양시간에 따라 급격히 감소하여 발 효 12 시간 후 대조군은 4.30 , 주박 효소 당화물 첨가군은 3.96 4.16으로 주박 효소 당화물의 사용량에 비례하여 감소하였 다. 적정산도는 $\mathrm{pH}$ 와 유사하게 증가하였으나 발효 12시간 후 대조군은 $0.93 \%$, 주박 효소 당화물 첨가군은 $0.84 \sim 1.04 \%$ 로 탈 지분유의 대체율이 낮은 조건(10 20\%)에서는 대조군보다 산의 생성이 증가되었지만 탈지분유의 $30 \%$ 이상을 대체하면 산의 생 성이 감소하였다. 젖산균 생균수는 발효 9시간까지 급격하게 증 가하여 대조군과 주박 효소 당화물 첨가군 모두 8.18 8.24 log $\mathrm{CFU} / \mathrm{g}$ 를 나타내었으나 발효 18 시간 후 탈지분유의 $30 \sim 50 \%$ 이 대체된 요구르트의 생균수는 7.54 7.69 $\log \mathrm{CFU} / \mathrm{g}$ 로 감소하였 다. 관능평가 결과 맛과 전체적인 기호도 항목에서 탈지분유의 $10 \sim 20 \%$ 를 주박 효소 당화물로 대체하여 제조한 요구르트가 대 조군과 유의적인 차이가 없었다. 탈지분유의 일부를 주박 효소 당화물로 대체한 요구르트를 $4{ }^{\circ} \mathrm{C}$ 에서 14 일간 저장하는 동안 $\mathrm{pH}$ 와 적정산도의 변화는 미미하였다. 그러나 젖산균 생균수는 주박 효소 당화물의 사용량에 비례하여 감소하였고, 탈지분유의 $10 \sim 20 \%$ 를 주박 효소 당화물로 대체하여 제조한 요구르트에서 저장 11 일까지 생균수가 $10^{7} \mathrm{CFU} / \mathrm{g}$ 이상으로 유지되었다.

Keywords 발효특성 · 요구르트 · 주박 효소 당화물 · 탈지분유 대체
감사의 글 본 연구는 2019년 청운대학교 연구년 지원을 받아 수행하였습니다.

\section{References}

1. Gilliland SE (1989) Acidophilus milk products, review of potential benefits to consumer. J Dairy Sci 72: 2483-2489

2. Sung YM, Cho JR, Oh NS, Kim DC, In MJ (2005) Preparation and quality characteristics of curd yogurt added with chlorella. J Korean Soc Appl Biol Chem 48: 60-64

3. Sung JM, Choi HY (2014) Effect of mulberry powder on antioxidant activities and quality characteristics of yogurt. J Korean Soc Food Sci Nutr 43: 690-697

4. Gahruie HH, Eskandari MH, Mesbahi G, Hanifpour MA (2015) Scientific and technical aspects of yogurt fortification: A review. Food Sci Human Well 4: 1-8

5. Shon SK, Rho TH, Kim HJ, Bae SM (1990) Takju brewing of uncooked rice starch using Rhizopus koji. Korean J Appl Microbiol Biotechnol 18: 506-510

6. Kim MS, Shin WC, Sohn HY (2015) Application of the lees of domestic traditional wine and its useful biological activity. J Life Sci 25: 10721079

7. Kim SM, Cho Wk (2006) Effects of Takju (Korean turbid rice wine) lees on the serum glucose levels in streptozotocin-induced diabetic rats. Korean J Food Culture 21: 638-643

8. Kang YJ, Park SJ, Bae K, Yoo JM, Pyo HB, Choi JH, Kim TJ (2011) Ethyl acetate extract of Korean rice wine lees inhibits IgE-mediated degranulation in rat basophilic leukemia RBL-2H3 cells and passive cutaneous anaphylaxis in mice. J Life Sci 21: 1364-1369

9. Kwon SC, Jeon TW, Park JS, Kwak JS, Kim TY (2012) Inhibitory effect of tyrosinase, ACE and xanthine oxidase, and nitrite scavenging activities of Jubark (alcohol filter cake) extracts. J Korean Soc Food Sci Nutr 41: 1191-1196

10. Park MJ, Kang HT, Kim MS, Shin WC, Sohn HY, Kim JS (2014) Antiinflammatory effects of extracts and their solvent fractions of rice wine lees. J Life Sci 24: 843-850

11. Park WY, Sung NY, Byun EH, Oh KH, Byun MW, Yoo YC (2015) Immuno-modulatory activities of polysaccharides separated from Jubak in microphage cells. J Korean Soc Food Sci Nutr 44: 1079-1083

12. Cho YH, Cho JS, Kim JY, Kim US, Choi JH, Park JH (2013) Quality characteristics of Sulgidduk with Makgeolli lees. J East Asian Soc Dietary Life 23: 227-233

13. Ko YS, Sim KH (2014) Quality characteristics and antioxidant activity of Jeung-pyun added with Ju-bak powder. J East Asian Soc Dietary Life 24: 190-200

14. Choi YS, Kim HW, Hwang KE, Song DH, Choi JH, Lee MA, Chung HJ, Kim CJ (2014) Physicochemical properties and sensory characteristics of reduced-fat frankfurters with pork back fat replaced by dietary fiber extracted from makgeolle lees. Meat Sci 96: 892-900

15. Im CY, Kim MH, Kang WW (2017) Quality characteristics of cookies added with Takju pomace powder. Korean J Food Preserv 24: 8-12

16. Lim YS, Bae SM, Kim K (2004) Production of yeast spores from rice wine cake. Korean J Microbiol Biotechnol 32: 184-189

17. Kim WS (2011) Utilization of Makgeolli sludge for growth of probiotic bacteria. CNU J Agric Sci 38: 473-477

18. Ko YJ, Ryu CH (2016) Optimum fermentation condition of apple vinegar added with Korean rice wine lees extracts. J Agric Life Sci 50: 193-200

19. Kim DC, In MJ (2016) Preparation and characteristics of yogurt added with Korean rice wine lees powder. J Appl Biol Chem 59: 345-349

20. Kim DC, Won SI, In MJ (2018) Preparation and characteristics of yogurt added with enzymatically saccharified Korean rice wine lees powder. J Appl Biol Chem 61: 315-320

21. In MJ, Choi SY, Kim HR, Park DB, Oh NS, Kim DC (2009) Acid 
production and phytate degradation using Leuconostoc mesenteroides KC51 strain in saccharified-rice suspension. J Appl Biol Chem 52: 33 37

22. Kim DC, Won SI, In MJ (2015) Substitution effect of enzymatically hydrolyzed purple sweet potato powder on skim milk in yogurt preparation. J Appl Biol Chem 58: 311-316

23. Lee JS, Bae I (2017) A study on the quality properties of yogurt containing Makgeolli (Korea rice-wine). J Milk Sci Biotechnol 35, 135 142

24. Shin KS, Lee JH (2018) Evaluation of quality characteristics in commercial yogurt. Korean J Food Preserv 25, 195-204
25. Chamber JV (1979) Culture and processing techniques important to the manufacture of good quality yogurt. Cult Dairy Prod J 14: 28-34

26. Lee HJ, Pak HO, Lee JM (2006) Fermentation properties of yogurt added with rice bran. Korean J Food Cookery Sci 22: 488-494

27. Won JI, Lee JH, Park HI, Cho YU, Choi ID, Lee SK, Park HY, Park JY, Oh SK, Han SI, Choi HS (2018) Quality characteristics of commercial semisolid type yogurt in Korea. J Korean Soc Food Sci Nutr 47: 1185 1190

28. Kosikowski F (1982) Cheese and fermented milk foods. Edwards Brothers Inc, Ann Arbor, MI, USA 